\title{
CCN3: a key growth regulator in Chronic Myeloid Leukaemia
}

\author{
Lynn McCallum • Wanhua Lu • Susan Price • \\ Noureddine Lazar • Bernard Perbal • \\ Alexandra E. Irvine
}

Received: 10 April 2009/Accepted: 15 June 2009 / Published online: 22 July 2009

(C) The Author(s) 2009. This article is published with open access at Springerlink.com

\begin{abstract}
Chronic Myeloid Leukaemia (CML) is characterized by expression of the constitutively active Bcr-Abl tyrosine kinase. We have shown previously that the negative growth regulator, $\mathrm{CCN} 3$, is down-regulated as a result of Bcr-Abl kinase activity and that $\mathrm{CCN} 3$ has a reciprocal relationship of expression with BCR-ABL. We now show that $\mathrm{CCN} 3$ confers growth regulation in $\mathrm{CML}$ cells by causing growth inhibition and regaining sensitivity to the induction of apoptosis. The mode of $\mathrm{CCN} 3$ induced growth regulation was investigated in K562 CML cells using gene transfection and treatment with recombinant CCN3. Both strategies showed CCN3 regulated CML cell growth by reducing colony formation capacity, increasing apoptosis and reducing ERK phosphorylation. K562 cells stably transfected to express CCN3 showed enhanced apoptosis in response to treatment with the tyrosine kinase inhibitor, imatinib. Whilst $\mathrm{CCN} 3$ expression was low or undetectable in CML stem cells, primary CD34+ CML progenitors were responsive to treatment with recombinant CCN3. This study shows that $\mathrm{CCN} 3$ is an important growth regulator in haematopoiesis, abrogation of $\mathrm{CCN} 3$ expression enhances BCR-ABL dependent leukaemogenesis.
\end{abstract}

\footnotetext{
L. McCallum $\cdot$ W. $\mathrm{Lu} \cdot \mathrm{S}$. Price $\cdot$ A. E. Irvine $(\bowtie)$

Centre for Cancer Research and Cell Biology,

Queen's University Belfast,

Lisburn Road,

Belfast BT9 7BL, UK

e-mail: s.irvine@qub.ac.uk

N. Lazar

Universite Paris 7D Diderot,

Paris 75005, France

B. Perbal

L'Oreal R \& D,

Clark, NJ 07066, USA
}

$\mathrm{CCN} 3$ restores growth regulation, regains sensitivity to the induction of apoptosis and enhances imatinib cell kill in CML cells. CCN3 may provide an additional therapeutic strategy in the management of CML.

Keywords CCN3 $\cdot$ Erk $\cdot$ Signalling $\cdot$ Apoptosis

\section{Introduction}

Chronic Myeloid Leukaemia (CML), a haematopoietic stem cell disorder, is characterised by the expression of the chimaeric bcr-abl fusion gene (or Philadelphia chromosome, $\mathrm{Ph}+$ ) formed from a reciprocal translocation between the bcr and abl genes on chromosomes 9 and 22 (Nowell and Hungerford 1960; Rowley 1973). The fusion gene encodes a constitutively active Bcr-Abl protein tyrosine kinase and expression culminates in alterations of cell proliferation, differentiation and resistance to the induction of apoptosis (Deininger et al. 2000; Jorgensen and Holyoake 2001). Expansion of the leukaemic clone presents as an accumulation of immature haematopoietic progenitor cells in the bone marrow (BM) and raised levels of myeloid cells in the peripheral blood (PB) (Clarkson et al. 1997; Wong and Witte 2001). CML is regarded as a triphasic disease; an indolent chronic phase of variable duration precedes progression to an accelerated phase leading on to the more severe blast crisis. The development of tyrosine kinase inhibitors (TKIs) has revolutionised the treatment of CML. Imatinib (Glivec, Gleevec), is now the gold standard and first line treatment for CML (Deininger and Holyoake 2005). Imatinib has been effective in inducing haematopoietic response in most cases and complete cytogenetic responses have been observed for $80-95 \%$ patients with chronic phase disease and $25-37 \%$ patients with advanced 
disease (accelerated and blast crisis) (Kumar 2006). Imatinib and its derivatives suppress but do not fully eradicate the leukaemic clone (Deininger and Holyoake 2005) and a proportion of patients remain unresponsive. An increasing number of patients are developing resistance to TKIs and it is clear that new treatment strategies are required.

We have previously identified down regulation of the negative growth regulator, $\mathrm{CCN} 3$, using DNA microarray analysis for a murine stem cell CML model to identify altered gene expression caused by the initial effects of BcrAbl kinase activity (McCallum et al. 2006). CCN3 is a member of the $\mathrm{CCN}$ family of growth regulatory proteins and roles for the $\mathrm{CCN}$ proteins are clearly established in fundamental biological processes such as cell proliferation, attachment, migration, differentiation, wound healing, angiogenesis and tumorigenesis (Perbal 2001). CCN proteins are multi-modular mosaic proteins containing four conserved modules which are present in other unrelated extracellular proteins. $\mathrm{CCN} 3$ comprises five distinct structural domains, a secretory peptide (SP) followed by the 4 conserved modules; insulin-like growth factor binding protein (IGFBP), Von Willebrand type C repeat (VWC), thrombospondin type I domain (TSP-1) and a cysteine knot carboxyl terminal (CT). CCN3 is mostly associated with exerting negative growth regulation. $\mathrm{CCN} 3$ was first isolated in a nephroblastoma model of Wilms's tumour where expression was associated with a differentiated phenotype and anti-proliferative activity (Chevalier et al. 1998). Although CCN3 was able to reduce the growth rate of Ewings sarcoma transfectants ex vivo (Scotlandi et al. 2003), CCN3 expression was associated with poor prognosis and shown to increase cell motility resulting in enhanced metastatic potential (Benini et al. 2005; Manara et al. 2002). Increased levels of CCN3 expression have been correlated with reduced tumorigenicity and low metastatic potential in glioblastomas ( $\mathrm{Li}$ et al. 1996) and an inverse relationship between $\mathrm{CCN} 3$ expression and tumour grade has been established for neuroblastoma and echondroma (Perbal 2001). CCN3 expression in conjunction with connexin-43 impaired human choriocarcinoma cell ability to induce tumour growth in vitro (Gellhaus et al. 2003). CCN3 is most commonly associated with negative growth regulation; reduced proliferation, cell differentiation and involvement in cell adhesion (Planque and Perbal 2003).

We have previously shown that $\mathrm{CCN} 3$ expression is low or absent in CML bone marrow (BM) mononuclear cells and expression increases to levels comparable with normal bone marrow (NBM) upon treatment with Imatinib (McCallum et al. 2006). This finding was also specific to the $\mathrm{CD} 34+$ progenitor cell population responsible for clonal expansion. In this study, we have used the human CML cell line (K562) to further investigate the mode of CCN3 induced growth regulation. We have evaluated the use of recombinant $\mathrm{CCN} 3(\mathrm{rCcn} 3)$ as an agent, alone and in combination with imatinib and then assessed primary human CML stem cell response to $\mathrm{rCcn} 3$.

\section{Materials and methods}

\section{Cell lines}

K562 cells were obtained from Deutsche Sammlung von Mikrorganismen und Zellkulturen (DSMZ, GmbH, Braunschweig, Germany) and HL-60 cells were obtained from the European Collection of Cell Cultures (ECACC, Salisbury, UK). All cell lines were maintained in RPMI1640 medium supplemented with $10 \%$ fetal calf serum (Gibco BRL, Paisley, UK) cultured at $37^{\circ} \mathrm{C}$ in a humidified atmosphere $\left(5 \% \mathrm{CO}_{2}\right.$ in air). Cells were subcultured twice weekly to maintain a log phase culture.

Primary CML samples and normal controls

Bone marrow aspirate samples and peripheral blood were obtained with informed consent from normal bone marrow donors and CML patients at diagnosis. All human samples were obtained with ethical approval from the local ethics review committee and those involved gave their informed consent for participation in accordance with the Declaration of Helsinki. Samples were collected in RPMI-1640 supplemented with $10 \%$ fetal calf serum and containing $100 \mathrm{IU}$ preservative free heparin (Leo Laboratories Ltd, Princes Risborough, UK). Mononuclear and neutrophil cells were separated over Ficoll-Hypaque (Pharmacia Biotech, Uppsala, Sweden) using standard procedures (English and Andersen 1974). CD34 positive cells were prepared using the MACS Direct CD34 Progenitor Cell Isolation kit (Miltenyi Biotech Ltd, Bisley, UK).

\section{CCN3 transfection of K562 cells}

K562 cells were nucleofected following the manufacturer's instructions using the Cell Line Nucleofector kit V, program T-16 (Amaxa, GmbH, Cologne, Germany) and transfected with $5 \mu \mathrm{g}$ of either vector (pCb6+; Invitrogen) or vector containing $\mathrm{CCN} 3$ sequence. Transfection was performed in triplicate and the functional consequences of $\mathrm{CCN} 3$ expression were evaluated 24 hours after transfection (mean transfected cells, $97.9 \% \pm 0.4 \%$ ). Protein was extracted and Western blotting performed to confirm CCN3 expression. To obtain cells stably expressing CCN3, K562 cells were nucleofected (as above) and stable transfectants were selected in G418 (Invitrogen) at a concentration of $800 \mu \mathrm{g} / \mathrm{ml}$. Cells transfected with the empty vector pCB6+ were used as a control. 
Treating K562 cells with recombinant CCN3 or imatinib

K562 cells $\left(1 \times 10^{6}\right)$ were treated with recombinant CCN3 (rCcn3; Peprotech EC, London, U.K.) in vitro and cultured at $37^{\circ} \mathrm{C}$ in a humidified atmosphere $\left(5 \% \mathrm{CO}_{2}\right.$ in air) for 24 and $48 \mathrm{~h}$. After $24 \mathrm{~h}$, cells were transferred to methyl cellulose culture (see below) and protein lysates were prepared (as described in Western Blotting). After $48 \mathrm{~h}$, cells were fixed and prepared for flow cytometric analysis (as described in Flow cytometry). K562 cells $\left(1 \times 10^{6}\right)$ were treated with imatinib $(1 \mu \mathrm{M}$ and $5 \mu \mathrm{M})$ for $96 \mathrm{~h}$. Cells were fixed and prepared for flow cytometric analysis (as described in Flow cytometry).

\section{Evaluation of clonogenic capacity}

Cells $\left(1 \times 10^{4}\right)$ were plated in triplicate in methyl cellulose (Miltenyi Biotech, U.K.) and incubated at $37^{\circ} \mathrm{C}$ in a humidified atmosphere $\left(5 \% \mathrm{CO}_{2}\right.$ in air) for 7 days. Colonies were counted using an inverted microscope (Olympus model 214034; Olympus, Tokyo, Japan; magnification $\times 40$ ).

\section{Western blot analysis}

Protein was extracted from cells by suspending in RIPA buffer ( $1 \times$ PBS, $1 \%$ Nonidet NP-40, $0.1 \%$ SDS) containing a cocktail of protease inhibitors (Complete Mini Cocktail, Roche Diagnostics Ltd, Lewes, UK) at a concentration of $10^{7}$ cells / $\mathrm{ml}$ and lysing for 10 minutes on ice. Samples were sonicated for 10 seconds to ensure complete lysis, centrifuged at $10,000 \mathrm{~g}$ at $4{ }^{\circ} \mathrm{C}$ for $10 \mathrm{~min}$ and the supernatant removed for analysis. Total protein content was determined by the Bradford protein method using the BCA protein assay kit (Pierce, Cramlington, UK). Protein $(15 \mu \mathrm{g})$ was loaded onto a pre-cast Bis-Tris polyacrylamide gel (10\%) using the Novex mini gel system (Invitrogen, Paisley, UK) and subsequently transferred to a PVDF membrane. CCN3 expression was detected using an antibody raised against the $\mathrm{C}$ terminal of $\mathrm{CCN} 3{ }^{22}$. Immunoblots were visualised by enhanced chemiluminescence (Supersignal West Pico and Supersignal West Dura substrates, Pierce).

Antibodies used in study

The K19M and NH5 antibodies were raised against the carboxyl terminal of CCN3 and were kindly provided by $\mathrm{B}$. Perbal. Both antibodies were diluted 1/1,000 in Western Breeze Blocker Diluent (Invitrogen, Paisley, U.K.) and used in the Western blotting procedure. Total ERK1/2 and phosphorylated ERK1/2 were detected using the p44/42 MAP kinase antibody (1/1,000, Cat\#9102; Cell Signaling Technology, Boston, MA, USA) and Phospho p44/42 MAP kinase antibody $(1 / 2,000$, Cat\#9106; Cell Signaling Technology, USA) respectively. Anti-cleaved Caspase-3 antibody (Cat\#96648; Cell Signaling Technology, USA) was used at a dilution of 1/1,000. Equivalent protein loading was controlled by monitoring actin expression using an anti-actin antibody (Cat\#4968; Cell Signalling Technologies, USA).

\section{Flow cytometry}

Cells $\left(5 \times 10^{5}\right)$ were fixed in $70 \%$ ethanol for flow cytometric analysis of cell cycle status. Fixed cells were resuspended in PBS and incubated in RNase A (100 mg/ $\mathrm{mL}$, Qiagen) and propidium iodide $(40 \mathrm{mg} / \mathrm{mL}$, Calbiochem) for 30 minutes at $37^{\circ} \mathrm{C}$. Samples were analyzed on a Coulter Epics Elite Cell Sorter (Beckman Coulter, High Wycombe, United Kingdom). Data were collected on the basis of peak signal versus integral signal to exclude doublets. Analysis was performed on 20,000 events using winMDI software (http://facs.scripps.edu/software.html) and data were generated and then ranked from a common gate in the $\mathrm{subG}_{0}$ area.

\section{Real-time PCR analysis of BCR-ABL and CCN3} expression

RQ-PCR was performed with an ABI PRISM 7500 Sequence Detector which exploits TaqMan probe based chemistry (Applied Biosystems, Foster City, CA). The 5' reporter used was 6-carboxyfluorescein (FAM) and the 3' quencher was 6-carboxy-tetramethylrhodamine (TAMRA). Primers and probes for $C C N 3$ were designed against GenBank published sequences in association with Primer Express (Applied Biosystems). Primer and probe sets for $B C R-A B L$ were used as recommended by the Europe Against Cancer protocol (Beillard et al. 2003; Gabert et al. 2003). The amplification reactions $(12.5 \mu \mathrm{L})$ contained 59 ng cDNA equivalents (or control), $1 \times$ Taqman universal PCR master mix, final concentrations of $5 \mathrm{mM} \mathrm{MgCl}_{2}$, $0.2 \mathrm{mM}$ deoxyadenosine deoxycytosine deoxyguanosine triphosphate (dATP/ dCTP/ dGTP), 0.4 deoxyuridine triphosphate ( dUTP), $0.125 \mathrm{U}$ AmpliTaq Gold, $2 \mu \mathrm{M}$ primers (forward and reverse) and $200 \mathrm{nM}$ TaqMan probe. Amplifications were performed following an initial 2-minute incubation at $50^{\circ} \mathrm{C}$ to allow uracil-N-glycosylase (UNG) to destroy any contaminating RNA, followed by treatment at $95^{\circ} \mathrm{C}$ for $10 \mathrm{~min}$ to inactivate the UNG enzyme and activate the AmpliTaq Gold DNA polymerase. This was followed by 40 to 45 cycles of denaturing at $95^{\circ} \mathrm{C}$ for $15 \mathrm{~s}$ and annealing/extension at $60^{\circ} \mathrm{C}$ for $1 \mathrm{~min}$. Data were collected and analysed with Sequence Detector v1.6.3 software (Applied Biosystems) as previously described (McCallum et al. 2006) to generate gene copy number. 


\section{Results}

CCN3 reduces cell growth and causes induction of apoptosis in K562 cells

To investigate the functional capacity of $\mathrm{CCN} 3$, we used both (i) transfection and (ii) recombinant protein to determine effect. Cell growth was measured using colony formation in methyl cellulose culture and was further evaluated using cell cycle analysis and Western blotting to detect the intracellular signaling events of caspase 3 cleavage and ERK phosphorylation.

\section{CCN3 expression exerts growth regulation in K562 cells}

CCN3 was transfected into K562 cells using nucleofector $^{\mathrm{TM}}$ technology and compared to cells transfected with

a

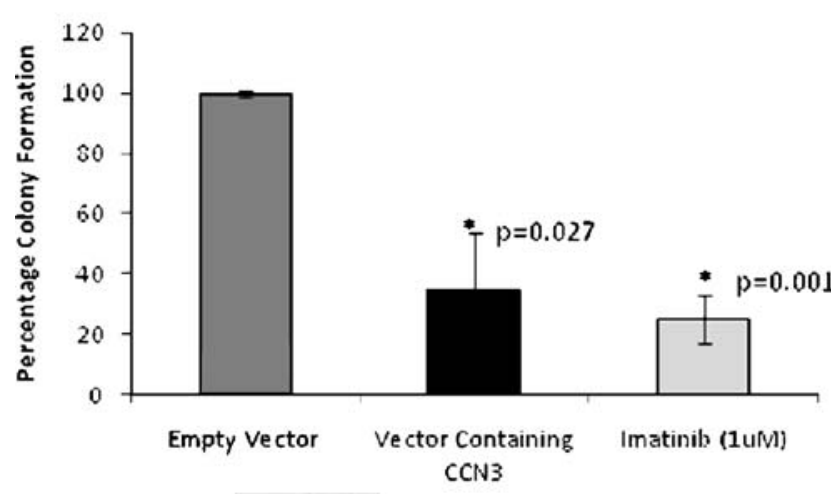

C
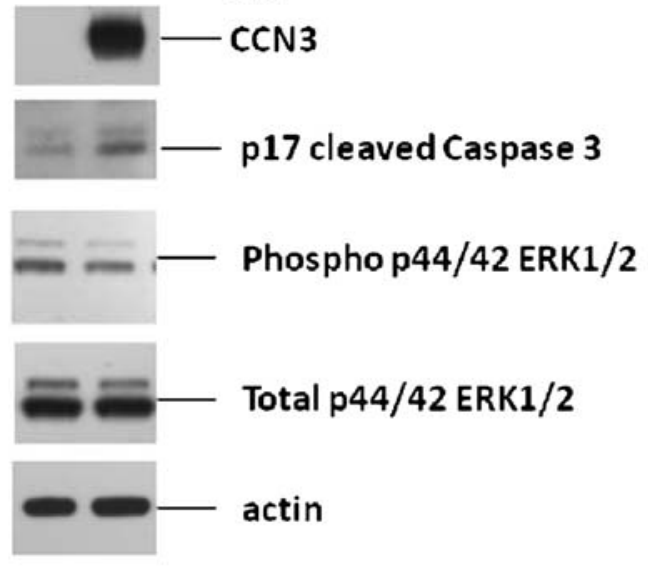

\section{i $\sum_{\mathrm{U}}^{\mathrm{m}}$}

Fig. 1 CML cells expressing CCN3 exhibit growth regulation. K562 cells transfected with $\mathrm{CCN} 3$ (CCN3) were compared to cells transfected with empty vector (EV) and cells treated with imatinib $(1 \mu \mathrm{M})$. Colony formation was measured after 7 days and is shown as a percentage of colony formation for cells transfected with empty vector (a). Induction of apoptosis was measured by the number of events within the sub $\mathrm{G}_{0}$ region of cell cycle; analysis was performed empty vector (EV) and cells treated with imatinib $(1 \mu \mathrm{M})$. Increased Ccn3 expression significantly reduced K562 cell colony formation capacity by $65.4 \% \pm 18.8$ to that of control $(n=3, p=0.027)$ (Fig. 1a). In addition, increased levels of $\mathrm{Ccn} 3$ caused cells to accumulate in the subG $\mathrm{G}_{0}$ region of cell cycle (Mean subG $\mathrm{G}_{0} 9.9 \% \pm 4.6$ for Control and $21.8 \% \pm 0.7$ for $\mathrm{Ccn} 3$ expressing cells $(\mathrm{n}=3, \mathrm{p}=0.027)$ (Fig. 1b). Western blot analysis showed that Ccn3 expression was undetected in K562 cells (EV) whilst transfection with vector containing $\mathrm{CCN} 3$ dramatically increased expression levels (Fig. 1c). Increased expression was accompanied by an increase in the levels of cleaved caspase 3 product and a reduction in phosphorylation of Erk2 (Mean reduction $42 \% \pm 10.4, \mathrm{n}=3 \mathrm{p}=0.01$ ) (Fig. 1c). Optical densitometry was performed to show changes in the magnitude of Erk phosphorylation and cleaved caspase 3 (Fig. 1d).

b

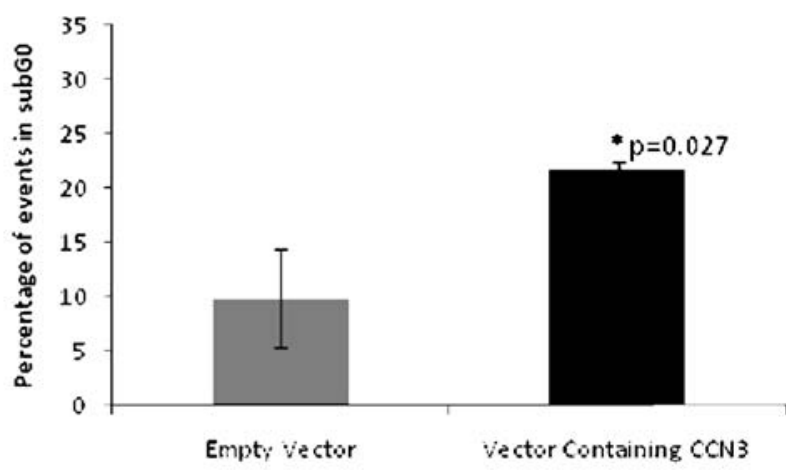

d

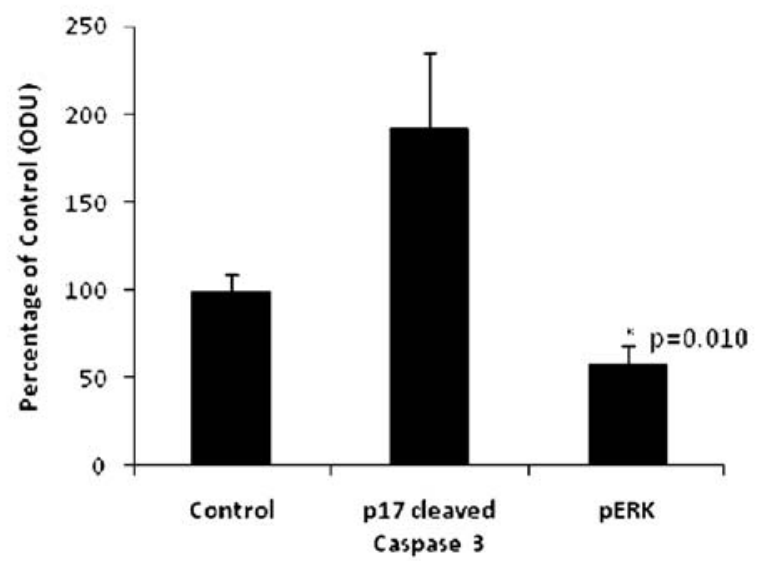

on 20,000 events using winMDI software and data were generated and then ranked from a common gate in the subG $\mathrm{G}_{0}$ area (b). Western blot analysis was performed to identify $\mathrm{Ccn} 3$ expression, accumulation of cleaved caspase 3 and levels of phosphorylated Erk1 and Erk2 (c). Actin expression is shown as a control for protein loading. Optical densitometry was performed to show changes in Erk phosphorylation and cleaved caspase 3 (d) 
K562 cells are responsive to treatment with recombinant CCN3

K562 cells were treated with recombinant $\mathrm{Ccn} 3$ ( $\mathrm{rCcn} 3$, $1 \mathrm{nM}$ ) and compared to untreated cells (Control). Cells treated with $\mathrm{rCcn} 3$ had reduced colony formation capacity $14 \% \pm 2.1$ compared to untreated cells (Fig. 2a) $(n=3, p=0.015)$. Similarly, rCcn3 caused an accumulation of cells within the $\mathrm{subG}_{0}$ area of cell cycle (Mean for $\mathrm{subG}_{0} 9.3 \% \pm 3.9$ and $23.7 \% \pm 6.9$ for control and $\mathrm{rCcn} 3$ respectively (Fig. 2b) $(n=3, p=0.014)$. Western blot analysis showed reduced Erk phosphorylation and an increase in cleaved caspase 3 levels as a consequence of rCcn3 treatment (Fig. 2c) $(n=3)$. Optical densitometry was performed to show alterations in levels of Erk phosphorylation and cleaved caspase 3 as a result of rCCN3 treatment (Fig. 2d).

a

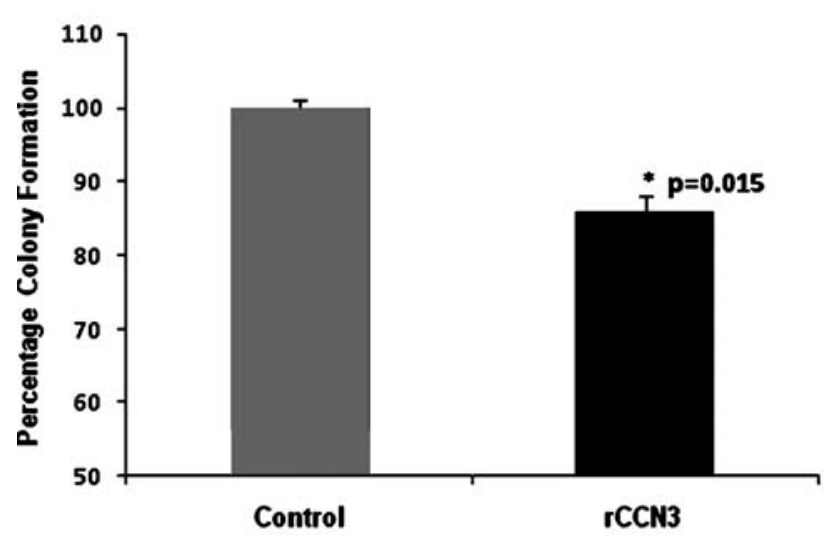

C

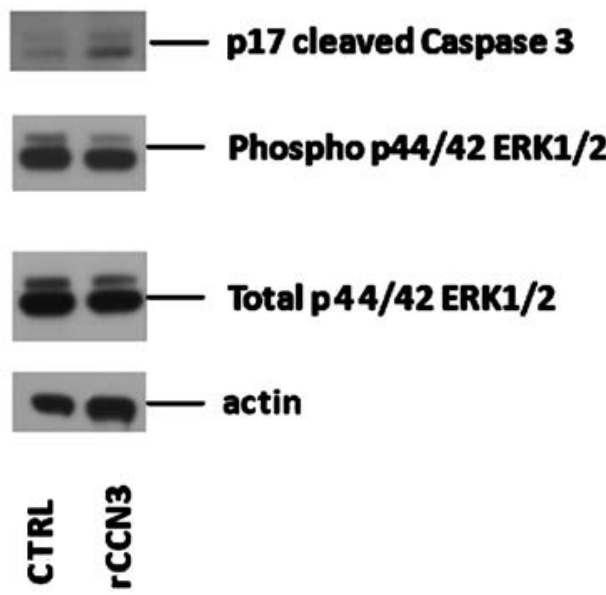

Fig. 2 CML cells respond to treatment with recombinant Ccn3. K562 cells treated with recombinant $\mathrm{Ccn} 3(\mathrm{rCcn} 3,1 \mathrm{nM})$ were compared to untreated cells (Control) and evaluated for growth regulation. Colony formation was measured after 7 days and is shown as a percentage of colony formation by control cells (a). Induction of apoptosis was measured by the number of events within the sub G0 region of cell cycle; analysis was performed on 20,000 events using winMDI
CCN3 expression enhances Imatinib induced apoptosis

Since CCN3 expression and treatment with recombinant Ccn3 restored growth regulation and induction of apoptosis in CML cells, we wished to investigate if $\mathrm{CCN} 3$ could augment imatinib induced cell death. K562 cells were transfected with vector or vector containing $\mathrm{CCN} 3$. Clones stably expressing vector constructs were selected using G418 resistance. Ccn3 expressing cells had a reduced growth rate compared to mock transfected cells (49\% reduction in growth by day 5, data not shown; ( $p=$ 0.005)). Cells expressing CCN3 (CCN3) or empty vector (Mock) were then untreated (control) or treated with Imatinib $(1 \mu \mathrm{M}$ or $5 \mu \mathrm{M})$ for $48 \mathrm{~h}$. CCN3 expression increased the number of events within the $\mathrm{subG}_{0}$ phase of cell cycle for both treatment with $1 \mu \mathrm{M}$ imatinib $(24.5 \% \pm$ 4.6 subG $_{0}$ events for $\mathrm{CCN} 3$ and $10.8 \% \pm 4.1$ for mock b

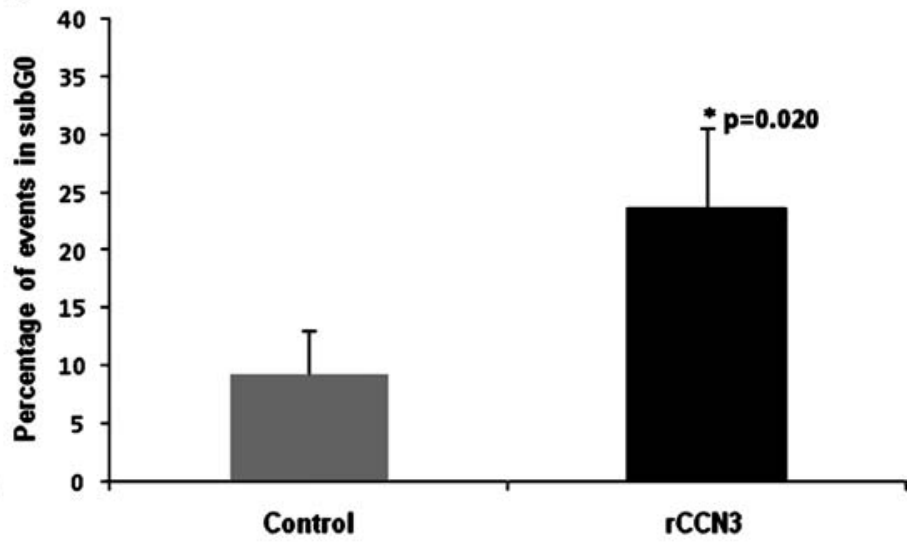

d

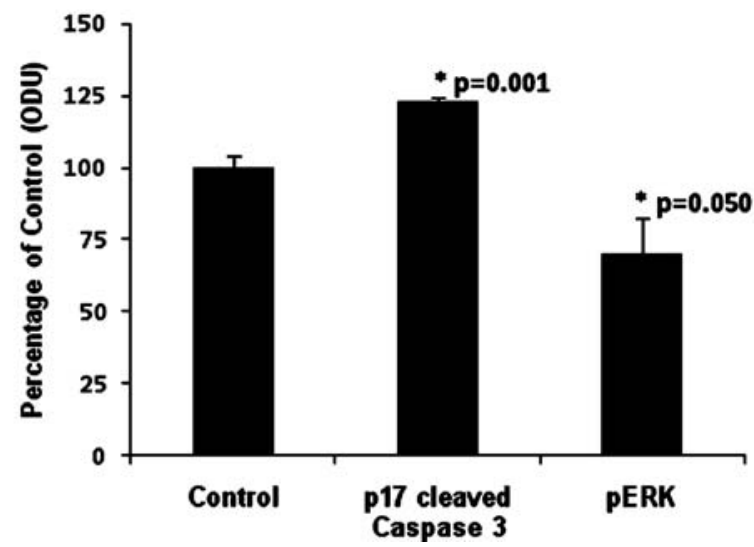

software and data were generated and then ranked from a common gate in the $\mathrm{subG}_{0}$ area (b). Western blot analysis was performed to identify accumulation of cleaved caspase 3 and levels of phosphorylated Erk1 and Erk2 (c). Actin expression is shown as a control for protein loading. Optical densitometry is shown for changes in Erk phosporylation and levels of cleaved caspase 3 for rCCN3 treated cells in comparison to control (d) 
transfected cells respectively $(\mathrm{n}=3, \mathrm{p}=0.040))$ and $5 \mu \mathrm{M}$ imatinib $\left(32.3 \% \pm 3.3 \mathrm{subG}_{0}\right.$ events for $\mathrm{CCN} 3$ and $16.1 \% \pm$ 2.8 for mock transfected cells respectively $(n=3, p=0.001)$ ) at $48 \mathrm{~h}$ (Fig. 3a). To further evaluate the magnitude and longevity of CCN3 enhanced apoptosis, CCN3 and mock transfected cells were treated with Imatinib $(5 \mu \mathrm{M})$ for 96 h. At 48 h, CCN3 expressing cells showed enhanced apoptosis in response to imatinib when compared to mock transfected cells $(45.0 \% \pm 6.7$ and $28.2 \% \pm 2.8$ of events in sub $\mathrm{G}_{0}$ for $\mathrm{CCN} 3$ and mock transfected cells respectively $(n=3, p=0.030$ (Fig. 3b). CCN3 expressing cells showed enhanced susceptibility to imatinib induced apoptosis at $72 \mathrm{~h}$ and $96 \mathrm{~h} ;(66.7 \% \pm 0.6$ and $44.2 \% \pm 1.8$ of events in sub $\mathrm{G}_{0}$ for $\mathrm{CCN} 3$ and mock transfected cells respectively at $72 \mathrm{~h}(\mathrm{n}=3, \mathrm{p}=0.001))$ and $(75.1 \% \pm 3.9$ and $52.7 \% \pm 1.9$ of events in sub $\mathrm{G}_{0}$ for $\mathrm{CCN} 3$ and mock transfected cells respectively at $96 \mathrm{~h}(\mathrm{n}=3, \mathrm{p}=0.002))$.

CCN3 expression is altered in CML

We have previously shown that CCN3 expression is downregulated as a consequence of Bcr-Abl kinase activity in
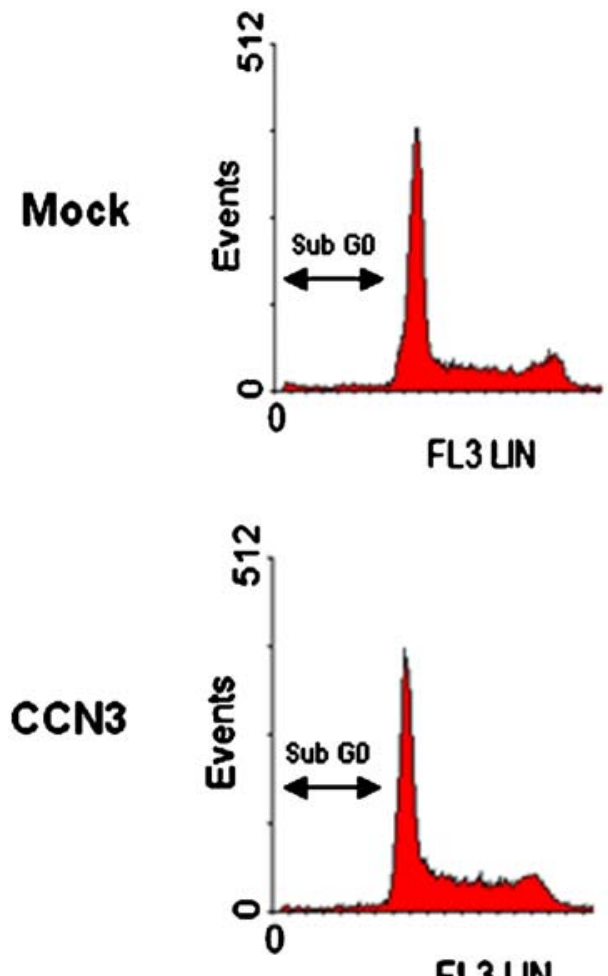

FL3 LIN

Control
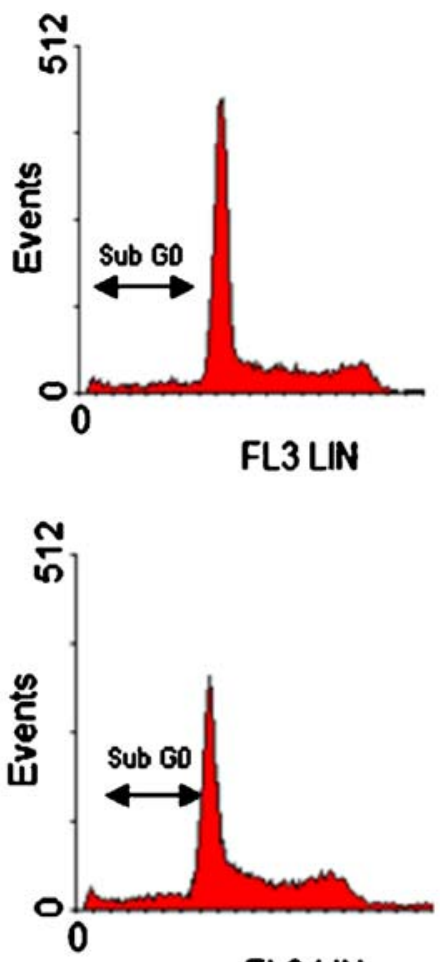

FL3 LIN

$1 \mu \mathrm{M}$
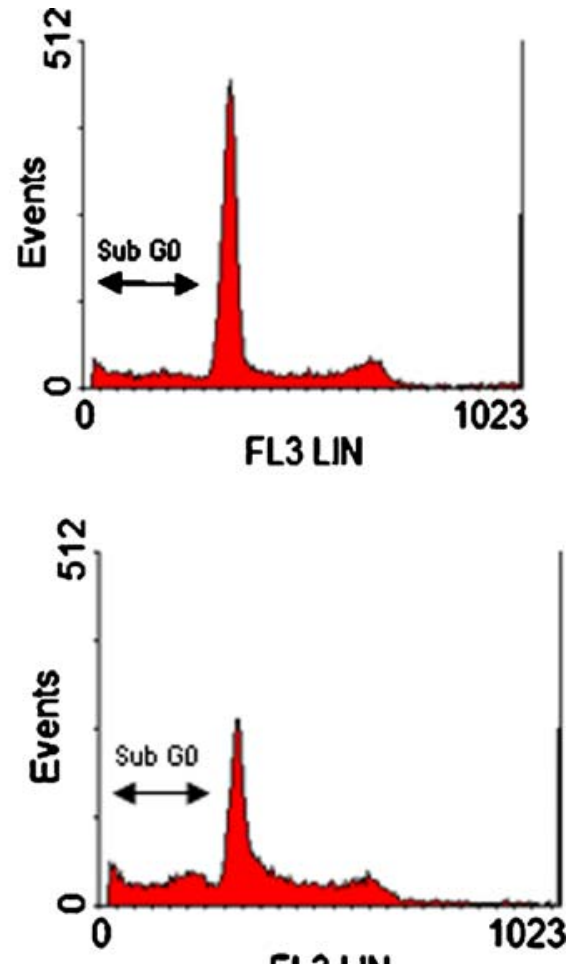

FL3 LIN

$5 \mu \mathrm{M}$

Imatinib Concentration

\begin{tabular}{|c|c|c|c|}
\hline SubG 0 events & Control & 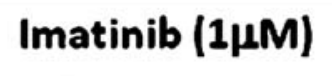 & 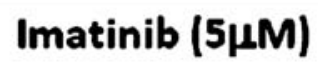 \\
\hline Mock & $3.7 \pm 1.6$ & $10.8 \pm 4.1$ & $16.1 \pm 2.8$ \\
\hline CCN3 & $5.8 \pm 0.8$ & $\begin{array}{l}24.5 \pm 4.6 \\
(p=0.04)\end{array}$ & $\begin{array}{l}32.3 \pm 3.3 \\
(p=0.001)\end{array}$ \\
\hline
\end{tabular}

Fig. 3 CCN3 expression enhances Imatinib induced apoptosis. K562 CML cells were stably transfected with $\mathrm{CCN} 3(\mathrm{CCN} 3)$ or vector alone (Mock) and treated with Imatinib $(1 \mu \mathrm{M}$ or $5 \mu \mathrm{M})$ for $48 \mathrm{~h}$. Flow cytometric analysis was performed on 20,000 events, data were then generated and ranked from a common gate in the $\mathrm{subG}_{0}$ area. The number of events in the subG $\mathrm{G}_{0}$ area for $\mathrm{CCN} 3$ and mock transfected cells are shown (a). $\mathrm{CCN} 3$ and mock transfected cells were treated with $5 \mu \mathrm{M}$ imatinib for a period of $96 \mathrm{~h}$ and flow cytometric analysis was performed (as above). The number of events in the $s \mathrm{bG}_{0}$ area for $\mathrm{CCN} 3$ and mock transfected cells are shown (b) 

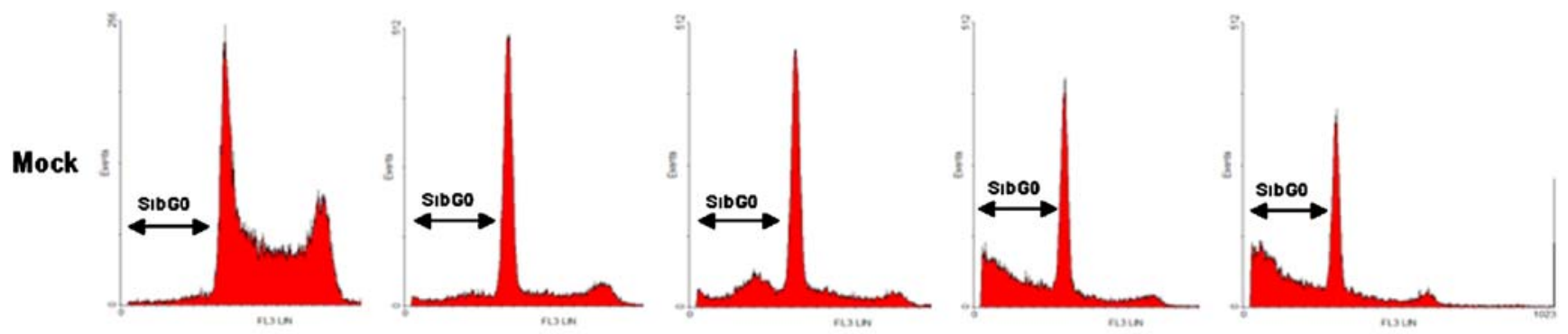

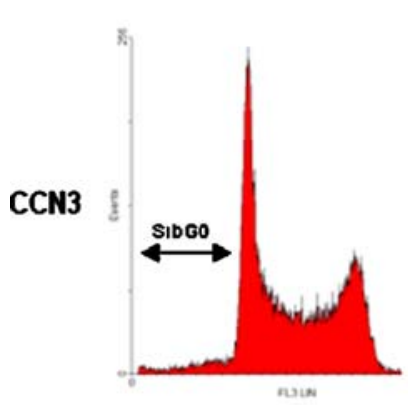

$\mathbf{0}$

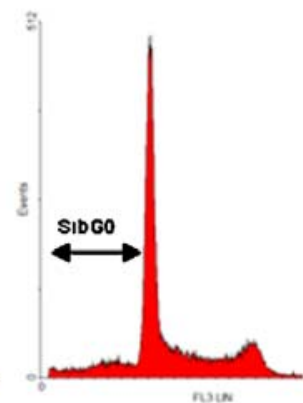

24

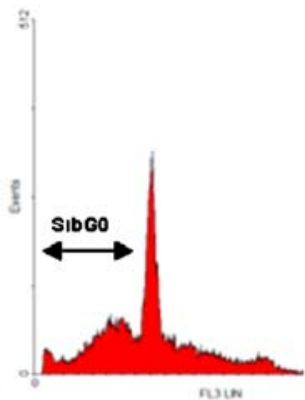

48

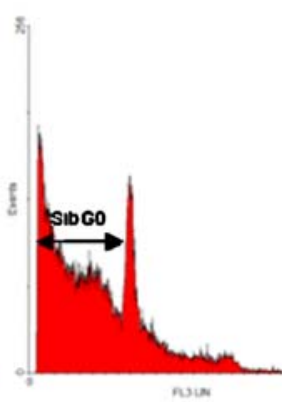

72

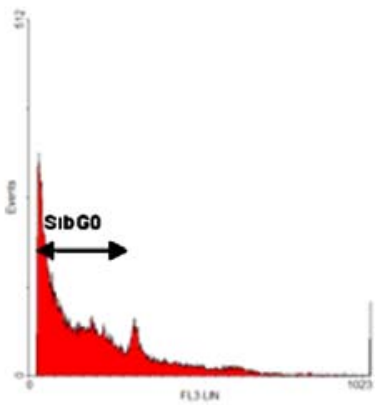

96

Duration of $5 \mu \mathrm{M}$ imatinib treatment (hours)

\begin{tabular}{llllll}
\hline $\begin{array}{l}\text { SubG } \\
\text { events }\end{array}$ & Oh & $24 \mathbf{h}$ & $\mathbf{4 8 h}$ & $\mathbf{7 2 h}$ & $\mathbf{9 6 h}$ \\
\hline Mock & $4.3 \pm 0.6$ & $13.1 \pm 0.5$ & $28.2 \pm 2.8$ & $44.2 \pm 1.8$ & $52.7 \pm 1.9$ \\
\hline CCN3 & $4.5 \pm 1.1$ & $12.7 \pm 1.9$ & $\begin{array}{l}45.0 \pm 6.7 \\
(p=0.030)\end{array}$ & $\begin{array}{l}66.7 \pm 0.6 \\
(p=0.001)\end{array}$ & $\begin{array}{l}75.1 \pm 3.9 \\
(p=0.002)\end{array}$ \\
\hline
\end{tabular}

Fig. 3 (continued)

CML. Further investigation of BCR-ABL and $\mathrm{CCN} 3$ expression was performed on $\mathrm{BM}$ and peripheral blood (PB) mononuclear cell extracts from CML patients at diagnosis. BCR-ABL expression was generally high (3.28 \pm $4.9 \times 10^{4}$ copies per $5 \mu \mathrm{l} \mathrm{cDNA}$ for BM and $1.34 \pm 1.1 \times 10^{4}$ copies per $5 \mu \mathrm{l}$ cDNA for $\mathrm{PB}$ ) whilst CCN3 expression was low $\left(6.13 \pm 5.6 \times 10^{2}\right.$ copies per $5 \mu \mathrm{cDNA}$ for BM and $2.58 \pm$ $3.7 \times 10^{3}$ copies per $5 \mu \mathrm{l}$ cDNA for PB) (Fig. $4 \mathrm{a}$ ). Analysis of individual patients following treatment with imatinib showed a clear trend; those with low or undetectable levels of CCN3 at diagnosis were more likely to achieve a $3 \log$ reduction within 6 months (optimal response), whilst those with higher levels of expression had a sub-optimal response to imatinib treatment (data not shown). To further investigate this phenomenon, protein was prepared from $\mathrm{CD} 34+$, mononuclear and neutrophil cells derived from NBM and from CML BM where the patient had a sub-optimal response to imatinib. Western blot analysis showed that $\mathrm{CCN} 3$ expression was high in normal CD34+ stem and mononuclear cells whilst CCN3 expression was undetectable in CML CD34+ stem cells and neutrophils (Fig. 4b). To then determine if primary human CML stem cells were responsive to $C \mathrm{cn} 3$, we treated CML CD34+ stem cells from peripheral blood samples at diagnosis with recombinant $\mathrm{Ccn} 3(\mathrm{rCcn} 3 ; 1 \mathrm{nM}-$ $1 \mathrm{pM})$ for $24 \mathrm{~h}$. Cells were then plated in methyl cellulose and counted after seven days. Treatment with imatinib $(1 \mu \mathrm{M})$ reduced the clonogenic capacity of CML CD34+ cells by $33.1 \% \pm 11.4(n=3, p=0.007)$ whilst treatment with $\mathrm{rCcn} 3$ showed dose dependent growth inhibition; $19.5 \% \pm 4.0$ for $1 \mathrm{nM}(\mathrm{n}=3, \mathrm{p}=0.001), 17.8 \% \pm 2.7$ for $100 \mathrm{pM}(\mathrm{n}=3, \mathrm{p}<$ 0.001 ) and $16.6 \% \pm 4.6$ for $10 \mathrm{pM} \mathrm{rCcn} 3$. Treatment with $1 \mathrm{pM} \mathrm{rCcn} 3$ did not significantly affect colony formation capacity (Fig. 4c).

\section{Discussion}

$\mathrm{CCN} 3$, a member of the $\mathrm{CCN}$ family of growth regulatory proteins has been shown to exert growth enhancing and growth inhibitory properties in a cell context specific manner. $\mathrm{CCN} 3$ is associated with increased invasive potential and metastasis in Ewings sarcoma (Benini et al. 2005; Manara et al. 2002) and is linked with expression of the multi drug resistant proteins in osteosarcoma (Perbal et 


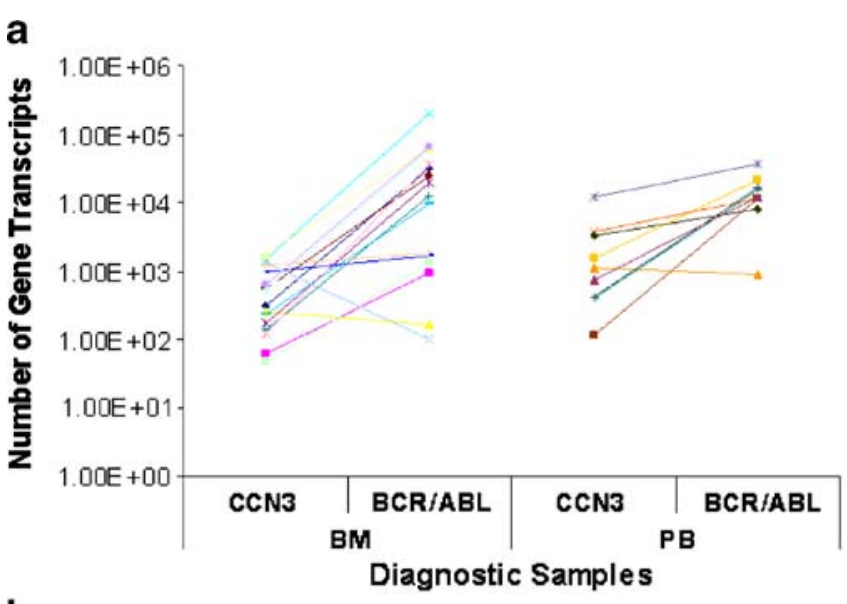

b
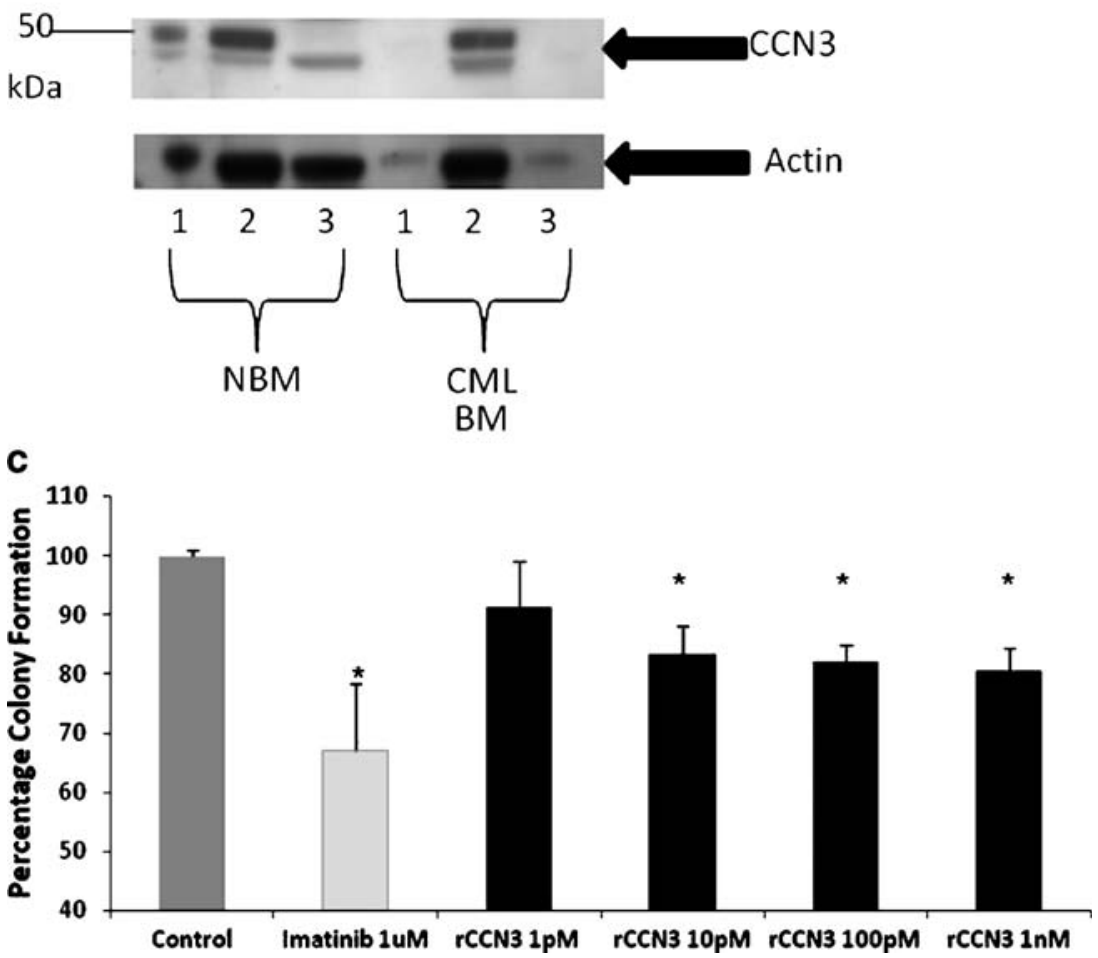

Fig. 4 Primary CML cells express low levels of CCN3 and respond to recombinant $\mathrm{Ccn} 3 . \mathrm{CCN} 3$ and $\mathrm{BCR}-\mathrm{ABL}$ levels at diagnosis were evaluated using Real-time PCR (EAC protocol for BCR-ABL expression). Gene copy number for $\mathrm{CCN} 3$ and $\mathrm{BCR}-\mathrm{ABL}$ expression levels were compared for $\mathrm{BM}(\mathrm{n}=16)$ and $\mathrm{PB}(\mathrm{n}=9)$ samples (a). Western blot analysis was performed to detect $\mathrm{Ccn} 3$ expression levels in extracts from CD34+(1), mononuclear (2) and neutrophil (3) cell preparations derived from NBM and CML BM at diagnosis. Ccn3 was

al. 2008). CCN3 is also a marker for prostatic cell transformation and early detection of malignancy (Maillard et al. 2001). In contrast, CCN3 acts as a tumour suppressor in melanoma, glioblastoma, adrenocortical tumours and in CML (McCallum and Irvine 2009). Reduced CCN3 expression is associated with the disorganized structure and increased proliferative capacity in the epidermis in melanoma and increased aggressiveness in glioblastomas detected using the NH5 antibody and expression is shown compared with levels of actin (b). Primary CML CD34+ cells $(n=3)$ were isolated from $\mathrm{CML}$ peripheral blood $(\mathrm{PB})$ at diagnosis. Cells were treated with $\mathrm{rCcn} 3(1 \mathrm{nM}-1 \mathrm{pM})$ or untreated (Control) for $24 \mathrm{~h}$ prior to plating in methyl cellulose. Colonies were counted after 7 days and are expressed as a percentage of colony formation compared to control $(\mathbf{c} *$ denotes $\mathrm{p}<0.05)$

(Fu et al. 2004; Fukunaga-Kalabis et al. 2007; Sin et al. 2007). CCN3 secretion is a recognised mechanism used in metastatic adrenocortical tumours and in CML cells to evade growth regulation. In CML, reduced expression of $\mathrm{CCN} 3$ is a direct consequence of Bcr-Abl kinase activity and cellular $\mathrm{Ccn} 3$ is rapidly exported to evade growth inhibition. In this report we have investigated CCN3 mode of regulation in CML cells. 
In a human CML cell line model (K562), overexpression of $\mathrm{CCN} 3$ or treatment with the recombinant protein results in a significant reduction in cell growth. The discrepancy between $\mathrm{CCN} 3$ expression and treatment with rCCN3 may be due to sustained CCN3 expression over the experimental period for colony formation ( 7 days) as opposed to a $24 \mathrm{~h}$ pre-treatment prior to plating in methyl cellulose culture. CCN3 reduced phosphorylation of Erk and increased apoptosis by enhancing caspase 3 cleavage. We have previously shown that reduced Erk phosphorylation as a consequence of the U0126 inhibitor, correlates with reduced clonogenic and proliferative capacity of K562 cells. CCN3 may compromise cell survival by reducing Erk phosphorylation causing decreased expression of prosurvival factors such as BCL-2, BCL- $\mathrm{x}_{\mathrm{L}}$ and MCL-1 (Balmanno and Cook 2009). CCN3 expression was shown to augment imatinib induced apoptosis and suggests $\mathrm{CCN} 3$ acts a tumour suppressor or pro-apoptotic factor.

We have previously shown CML patients at diagnosis have low or undetectable levels of CCN3 and CML CD34+ stem cells have low $\mathrm{CCN} 3$ expression which increases in response to imatinib treatment (McCallum et al. 2006). Ongoing monitoring of CML patients has subsequently demonstrated that a sub-population of patients have higher levels of CCN3 at diagnosis. These patients did not achieve a $3 \log$ reduction in BCR-ABL levels within 6 months which is known to be associated with poorer prognosis. Analysis of Ccn3 protein within these samples showed that although mononuclear cells expressed $\mathrm{Ccn} 3$, the stem cell population had low or undetectable levels of Ccn3 expression. Since Ccn3 is clearly expressed in stem, mononuclear and neutrophil cells in NBM, CCN3 downregulation is a key event in BCR-ABL leukaemogenesis. CCN3 appears to compromise BCR-ABL+ cell resistance to the induction of apoptosis. Primary CML CD34+ stem cells were responsive to recombinant $\mathrm{Ccn} 3$ which demonstrates a novel avenue for further evaluation in the management of CML.

$\mathrm{CCN} 3$ is a key regulator of haematopoiesis; de-regulation within this pathway enhances BCR-ABL leukaemogenesis by promoting cell survival and eliminating pro-apoptotic factors through the Erk signalling pathway. Manipulation of $\mathrm{Ccn} 3$, provides a novel strategy for therapeutic intervention to overcome oncogene mediated survival signals and restore apoptosis.

Acknowledgements This work has been supported by the Leukaemia Research Fund (LRF, UK), Northern Ireland Leukaemia Research Fund (NILRF, UK) and the Elimination of Leukaemia Fund (ELF, UK).

Open Access This article is distributed under the terms of the Creative Commons Attribution Noncommercial License which permits any noncommercial use, distribution, and reproduction in any medium, provided the original author(s) and source are credited.

\section{References}

Balmanno K, Cook SJ (2009) Tumour cell survival signalling by the ERK1/2 pathway. Cell Death Differ 3:368-377

Beillard E, Pallisgaard N, van der Velden VH, Bi W, Dee R, van der Schoot E, Delabesse E, Macintyre E, Gottardi E, Saglio G et al (2003) Evaluation of candidate control genes for diagnosis and residual disease detection in leukemic patients using 'real-time' quantitative reverse-transcriptase polymerase chain reaction (RQPCR) - a Europe against cancer program. Leukemia 12:24742486

Benini S, Perbal B, Zambelli D, Colombo MP, Manara MC, Serra M, Parenza M, Martinez V, Picci P, Scotlandi K (2005) In Ewing's sarcoma CCN3(NOV) inhibits proliferation while promoting migration and invasion of the same cell type. Oncogene 27:4349-4361

Chevalier G, Yeger H, Martinerie C, Laurent M, Alami J, Schofield PN, Perbal B (1998) novH: differential expression in developing kidney and Wilm's tumors. Am J Pathol 6:1563-1575

Clarkson BD, Strife A, Wisniewski D, Lambek C, Carpino N (1997) New understanding of the pathogenesis of CML: a prototype of early neoplasia. Leukemia 9:1404-1428

Deininger MW, Goldman JM, Melo JV (2000) The molecular biology of chronic myeloid leukemia. Blood 10:3343-3356

Deininger MW, Holyoake TL (2005) Can we afford to let sleeping dogs lie? Blood 5:1840-1841

English D, Andersen BR (1974) Single-step separation of red blood cells. Granulocytes and mononuclear leukocytes on discontinuous density gradients of Ficoll-Hypaque. J Immunol Methods $3: 249-252$

Fu CT, Bechberger JF, Ozog MA, Perbal B, Naus CC (2004) CCN3 (NOV) interacts with connexin43 in $\mathrm{C} 6$ glioma cells: possible mechanism of connexin-mediated growth suppression. J Biol Chem 35:36943-36950

Fukunaga-Kalabis M, Martinez G, Telson SM, Liu ZJ, Balint K, Juhasz I, Elder DE, Perbal B, Herlyn M (2007) Downregulation of $\mathrm{CCN} 3$ expression as a potential mechanism for melanoma progression. Oncogene 27:2552-60

Gabert J, Beillard E, van der Velden VH, Bi W, Grimwade D, Pallisgaard N, Barbany G, Cazzaniga G, Cayuela JM, Cave H et al (2003) Standardization and quality control studies of 'real-time' quantitative reverse transcriptase polymerase chain reaction of fusion gene transcripts for residual disease detection in leukemia a Europe Against Cancer program. Leukemia 12:2318-2357

Gellhaus A, Propson S, Gabriel HD, Gruemmer R, Duerig J, KleinHitpass BL, Maass K, Perbal B, Winterhager E (2003) NOV is associated with $\mathrm{CX} 3$ but not with $\mathrm{CX} 0$ and TRCX43 in human choriocarcinoma transfectants: evidence for potential growthregulatory functions. Mol Pathol 56:75

Jorgensen HG, Holyoake TL (2001) A comparison of normal and leukemic stem cell biology in Chronic Myeloid Leukemia. Hematol Oncol 3:89-106

Kumar L (2006) Chronic myelogenous leukaemia (CML): an update. Natl Med J India 5:255-263

Li WX, Martinerie C, Zumkeller W, Westphal M, Perbal B (1996) Differential expression of novH and CTGF in human glioma cell lines. Mol Pathol 91-97.

Maillard M, Cadot B, Ball RY, Sethia K, Edwards DR, Perbal B, Tatoud R (2001) Differential expression of the ccn3 (nov) protooncogene in human prostate cell lines and tissues. Mol Pathol 4:275-280

Manara MC, Perbal B, Benini S, Strammiello R, Cerisano V, Perdichizzi S, Serra M, Astolfi A, Bertoni F, Alami J et al (2002) The expression of ccn3(nov) gene in musculoskeletal tumors. Am J Pathol 3:849-859 
McCallum L, Irvine AE (2009) CCN3-a key regulator of the hematopoietic compartment. Blood Rev 2:79-85

McCallum L, Price S, Planque N, Perbal B, Pierce A, Whetton AD, Irvine AE (2006) A novel mechanism for BCR-ABL action: stimulated secretion of $\mathrm{CCN} 3$ is involved in growth and differentiation regulation. Blood 5:1716-1723

Nowell PC, Hungerford D (1960) A minute chromosome in human chronic granulocytic leukaemia. Science 132:1497

Perbal B (2001) NOV (nephroblastoma overexpressed) and the CCN family of genes: structural and functional issues. Mol Pathol 2:57-79

Perbal B, Zuntini M, Zambelli D, Serra M, Sciandra M, Cantiani L, Lucarelli E, Picci P, Scotlandi K (2008) Prognostic value of CCN3 in osteosarcoma. Clin Cancer Res 3:701-709
Planque N, Perbal B (2003) A structural approach to the role of CCN (CYR61/CTGF/NOV) proteins in tumourigenesis. Cancer Cell Int 1:15

Rowley ID. (1973). A new consistent chromosomal abnormality in chronic myelogenous leukaemia identified by quinacrine fluorescence and Giemsa staining. Nature 290-3.

Scotlandi K, Benini S, Manara MC, Cerisano V, Perdichizzi S, Strammiello R, Perbal B (2003). Biological role of NOVH in Ewings sarcoma cells. Mol Pathol 73

Sin WC, Bechberger JF, Rushlow WJ, Naus CC (2008) Dosedependent differential upregulation of $\mathrm{CCN} 1 / \mathrm{Cyr} 61$ and $\mathrm{CCN} 3 /$ NOV by the gap junction protein Connexin43 in glioma cells. $\mathrm{J}$ Cell Biochem 103:1772-1782

Wong S, Witte ON (2001) Modelling Philadelphia chromosome positive leukemias. Oncogene 20:5644-5659 